\title{
FIELD TFIALS ON THE STORE DRESSING WITH ROCK PHOSPHATE
}

\author{
Pentti Hänninen
}

Agricultural Research Centre, Movable field experiments in Central Finland, Kunsa as.

Armi KaIla

University of Helsinki, Department of Agricultural Chemistry Helsinki

Received April 4, 1960

Most Finnish soils are poor in plant-available phosphorus, and phosphate fertilizers are needed for the production of satisfactory yields. It has been supposed that by using a heavy store dressing even our soils could be saturated with phosphorus to such de $r$ ree that no response to an annual application of phosphate would occur. Particularly, in the years after the second world war this idea was favoured.

In the present paper the validity of this assumption is studied on the basis of two field trial:s in which the rock phosphate Hyperphosphate Reno was used as the store dressing. The analyses of the experimental soils and the yield results gave the followirg answer to this question.

\section{Material and methods}

The two field trials of five years standing were started in 1955 when the phosphate treatments for the nurse crop o: a clover-timothy ley were the following:

1. No phosphate

2. $1000 \mathrm{~kg} / \mathrm{ha}$ of hyperphosphate

3. $2000 \mathrm{~kg} / \mathrm{ha}$ of hyperphosphate

The nurse crop in trial K 100 was oats, in trial K 101 it was barley. Since 1956 the effectiveness of the store dressing on the ley was compared with the increase produced by an additional annual application of $200 \mathrm{~kg} / \mathrm{ha}$ of superphosphate. This was performed by applying the split plot technique. In the autumn 1958 the ley of trial K 100 was ploughed under and rye was sowed without any application of phosphate fertilizers. Thus the rye yield may be supposed to show the residual effect of the phosphate treatments.

For the main treatments, the plots in trial $\mathrm{K} 100$ were $70 \mathrm{~m}^{2}$, and the plots of trial $\mathrm{K} 101$ were $80 \mathrm{~m}^{2}$. For the sub-triatments, the area of the plots were $35 \mathrm{~m}^{2}$ and $40 \mathrm{~m}^{2}$, respectively. The harvested 
areas of the sub-plots were generally 16 or $17 \mathrm{~m}^{2}$. Both the main treatments and the sub-treatments within a block were randomised, and the whole experiments consisted of four blocks.

According to the manufacturer's analysis the hyperphosphate used contained $12.5 \%$ of $\mathrm{P}$, the $\mathrm{P}$ content of superphosphate varied between 7.9 and $8.5 \%$ in different years, and was on average $\mathbf{8 . 3} \%$. The hyperphosphate was carefully worked in with a spade harrow. The superphosphate was applied as a surface dressing to the ley.

The annual basal dressing in both the trials consisted of $100 \mathrm{~kg} / \mathrm{ha}$ of $50 \%$ potash fertilizer for the nurse crop, $100 \mathrm{~kg} / \mathrm{ha}$ of $50 \%$ potash fertilizer and $100 \mathrm{~kg} / \mathrm{ha}$ of nitrochalk for the ley, and $100 \mathrm{~kg} / \mathrm{ha}$ of calcium nitrate for the rye in the spring.

The data in Table 1 characterize the experimental soils. In general, the soil of trial $\mathrm{K} 101$ seems to be sbetter than that of trial $\mathrm{K}$ 100. The differences in the particular figures are well in accordance with the somewhat higher acidity of the soil in trial $\mathrm{K} 100$.

Table 1. Experimental soils

Soil
$\mathrm{pH}_{\mathrm{H}_{2} 0}$
Org. C \%
Extractable $\mathrm{Ca}$ ppm
$\mathrm{Fe}$ in acid oxalate extract ppm
$\mathrm{Al}$,
$\mathrm{P}$ ppm soluble in $0.5 \mathrm{~N}$ acetic acid
$\mathrm{P}, 0.03 \mathrm{~N} \mathrm{NH}_{4} \mathrm{~F}-0.025 \mathrm{NCl}$
$\mathrm{P}$ mg/l in soil solution,
Indicator of phosphate retention

$\begin{array}{rr}\text { Trial K } 100 & \text { Trial K } 100 \\ \text { loam } & \text { silt } \\ 5.3 & 6.2 \\ 4.5 & 3.3 \\ 1760 & 2540 \\ 220 & 300 \\ 70 & 50 \\ 4350 & 3770 \\ 3220 & 2650 \\ 13 & 18 \\ 10 & 9 \\ 120 & 73 \\ 0.46 & 0.51 \\ 167 & 98\end{array}$

Soil samples were collected from trial K 100 in 1958 and from trial K 101 in 1959. A special soil auger was used which allowed a fairly reliable sampling from the depths of 0 to 1 inch, 1 to 3 inches, and from 3 to 5 inches. Ten cores were taken from each of the sub-plots and samples from the same depth were bulked for each subplot. The samples were air-dried and ground.

Hay samples were collected from each subplot in trial K 101 in 1959 and analyzed for total phosphorus using the ammonium vanadate-molybdate method of GERICKE and Kurmies (2).

The phosphorus condition of the variously treated soils was studied in several ways. The acetic acid soluble $\mathrm{P}$ was determined by using $0.5 \mathrm{~N}$ acid in the ratio of $1: 10$, the shaking period being half an hour. $\mathrm{P}$ soluble in $0.03 \mathrm{~N} \mathrm{NH}_{4} \mathrm{~F}-0.025 \mathrm{~N} \mathrm{HCl}$ was extracted in the ratio of 1:10 by shaking for one minute. The exchangeable $\mathrm{P}_{\mathrm{n}}$ represents the inorganic phosphorus in an alkali extract, $0.1 \mathrm{~N}$ with respect to potassium hydroxide and potassium carbonate; the ratio of soil to solution was 1 to 50 , and the shaking time was $2+4$ hours in two consecutive days. The ${ }^{\mathrm{P}}$ in soil solution was, according to TERÄSVUORI (4), calculated on the basis of the Freundlich adsorption isotherm to correspond to the equilibrium $\mathrm{P}$ concentration when the data for the vexchangeable $\mathrm{P}$ r represent the adsorbed phosphate. The fractionation of inorganic phosphorus was performed by the method introduced by $\mathrm{C}_{\mathrm{HANG}}$ and JAckson (1).

The $\mathrm{pH}$-values refer to $1: 2.5$ water suspension.

\section{Results of soil analyses}

The phosphorus condition of the soil samples from the different treatments is characterized by the data reported for trial $\mathrm{K} 100$ in Table 2 and for trial $\mathrm{K} 101$ in Table 3. The total amounts of phosphorus applied to the soils correspond to 
Table 2. pF--values and phosphorus conditions in the soil of trial $\mathrm{K} 100$ in 1958

\begin{tabular}{lccccc}
\hline $\begin{array}{l}\text { Hyperphosphate } \\
\mathrm{kg} / \mathrm{ha} \text { in } 1955\end{array}$ & \multicolumn{3}{c}{ Without superphosphate } & Superphosphate annually $1956-58$ \\
\hline
\end{tabular}

\begin{tabular}{|c|c|c|c|c|c|c|}
\hline $\begin{array}{l}\text { Depth } \\
\text { inches }\end{array}$ & & & $\mathrm{pH}_{\mathbf{H}_{2}}$ & & & \\
\hline $0-1$ & 5.4 & 5.3 & 5.4 & 5.3 & 5.3 & 5.3 \\
\hline $1-3$ & 5.4 & 5.3 & 5.4 & 5.3 & 5.2 & 5.3 \\
\hline $3-5$ & 5.1 & 5.1 & 5.1 & 5.1 & 5.0 & 5.1 \\
\hline
\end{tabular}

$\mathrm{P}$ ppm soluble in $0.5 \mathrm{~N}$ acetic acid

$\begin{array}{rrrrrrrr}0-1 & 13 & 36 & 99 & 21 & 60 & 130 & 106 \\ 1-3 & 13 & 32 & 83 & 14 & 35 & 20 \\ 3-5 & 14 & 16 & 20 & 21 & 20 & 22\end{array}$

P ppm soluble in $0.03 \mathrm{~N} \mathrm{NH}_{4} \mathrm{~F}-0.025 \mathrm{~N} \mathrm{HCl}$

$\begin{array}{lrllllll}0-1 & 10 & 14 & 17 & 36 & 46 & 44 \\ 1-3 & 9 & 12 & 14 & 11 & 17 & 16 & 11 \\ 3-5 & 10 & 11 & 10 & 14 & 14 & 5\end{array}$

Exchangeable» P ppm

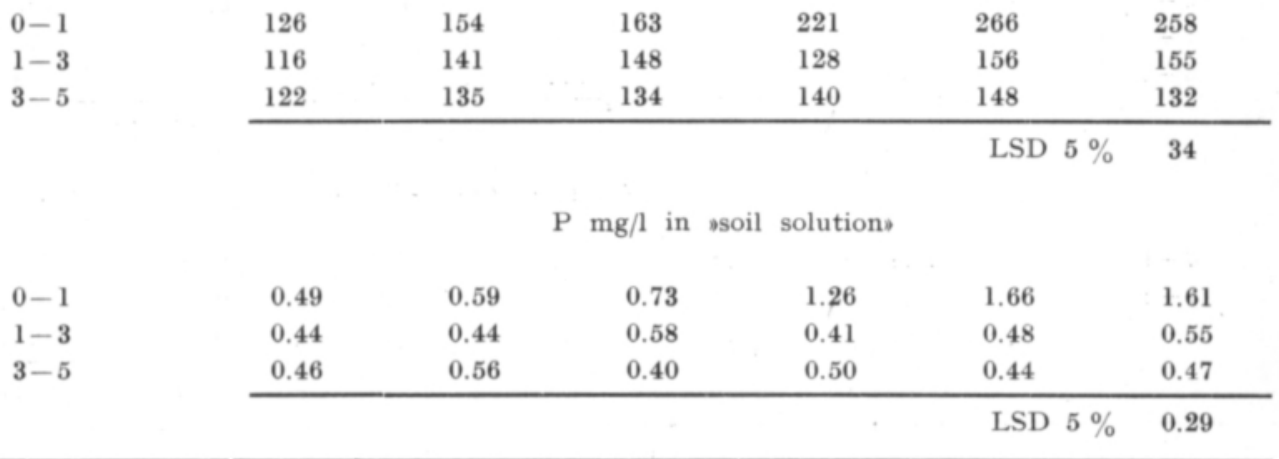

125 and $250 \mathrm{~kg} / \mathrm{hil}$ of rock phosphate $\mathrm{P}$ in the store dressing with 1000 and 2000 $\mathrm{kg} / \mathrm{ha}$ of hyperphosphate, respectively. The annual surface applications amount to $50 \mathrm{~kg} / \mathrm{ha}$ of superphosphate $\mathrm{P}$ in trial $\mathrm{K} 100$ and to $66 \mathrm{~kg} / \mathrm{ha}$ of superphosphate $\mathrm{P}$ in trial $\mathrm{K} 101$.

The pH-values do not reveal any liming effect of hyperphosphate or any increase in the acidity due to the superphosphate treatment. In trial $\mathrm{K} 100$ the lowest layer sampled is somewhat more acid than the surface ones, in trial K 101 a contrary tendericy may be detected. 
Table 3. pH-values and phosphorus condition in the soil of trial $\mathrm{K} 101$ in 1959

\begin{tabular}{|c|c|c|c|c|c|c|}
\hline \multirow{2}{*}{$\begin{array}{l}\text { Hyperphosphate } \\
\mathrm{kg} / \mathrm{ha} \text { in } 1955\end{array}$} & \multicolumn{3}{|c|}{ Without superphosphate } & \multicolumn{2}{|c|}{ Superphosphate annually } & \multirow{2}{*}{$\begin{array}{c}1956-59 \\
2000\end{array}$} \\
\hline & 0 & 1000 & 2000 & 0 & 1000 & \\
\hline $\begin{array}{l}\text { Depth } \\
\text { inches }\end{array}$ & & & $\mathrm{pH}_{\mathrm{H}_{2} 0}$ & & & \\
\hline $0-1$ & 6.2 & 6.1 & 6.2 & 6.1 & 6.2 & 6.1 \\
\hline $1-3$ & 6.2 & 6.3 & 6.2 & 6.2 & 6.4 & 6.2 \\
\hline \multirow[t]{2}{*}{$3-5$} & 6.3 & 6.3 & 6.3 & 6.3 & 6.3 & 6.3 \\
\hline & & & & & LSD 5 & 0.15 \\
\hline
\end{tabular}

$\mathrm{P}$ ppm soluble in $0.5 \mathrm{~N}$ acetic acid

\begin{tabular}{rrrrrrr}
$0-1$ & 16 & 45 & 99 & 22 & 77 & 158 \\
$1-3$ & 18 & 32 & 66 & 18 & 38 & 116 \\
$3-5$ & 19 & 19 & 21 & 16 & 19 & 23 \\
\hline & & & & LSD $5 \%$ & 44
\end{tabular}

P ppm soluble in $0.03 \mathrm{~N} \mathrm{NH}[\mathrm{F}-0.025 \mathrm{~N} \mathrm{HCl}$

$1-0$
$1-3$
$3-5$

\begin{tabular}{rrrrlr}
12 & 17 & 21 & 38 & 49 & 50 \\
8 & 9 & 12 & 11 & 13 & 16 \\
9 & 10 & 12 & 10 & 10 & 12 \\
\hline
\end{tabular}

•Echangeable» $\mathrm{P}$ ppm

\begin{tabular}{rrrrrrr}
$0-1$ & 77 & 104 & 111 & 148 & 182 & 182 \\
$1-3$ & 71 & 74 & 89 & 72 & 87 & 87 \\
$3-5$ & 72 & 103 & 100 & 78 & 81 & 89 \\
\cline { 2 - 7 } & & & & LSD 5\% & 34
\end{tabular}

$\mathrm{P} \mathrm{mg} / \mathrm{l}$ in ssoil solution

\begin{tabular}{lllllll}
$0-1$ & 0.69 & 1.08 & 1.16 & 1.77 & 2.55 & 2.86 \\
$1-3$ & 0.51 & 1.01 & 0.65 & 0.53 & 0.52 & 0.70 \\
$3-5$ & 0.43 & 0.55 & 0.53 & 0.53 & 0.46 & 0.44 \\
\cline { 2 - 7 } & & & & LSD $5 \%$ & 0.37
\end{tabular}

Owing to the large variation in the soil between the blocks of the trials, the values for the least significant difference at five per cent level calculated for the whole trial are fairly high. Yet, some distinct features may be found in the phosphorus test values in both trials.

The effect of superphosphate on the phosphorus data is almost completely restricted to the surface inch. The only exception exists in the acetic acid soluble $\mathrm{P}$ in the soil treated with $2000 \mathrm{~kg} / \mathrm{ha}$ of hyperphosphate: in both trials the superphosphate subplots contain more acetic acid soluble $\mathrm{P}$ in the layer from 1 to 3 inches than the corresponding untreated plots. 
Also the effest of the store dressing with rock phosphate is most apparent in the phosphorus values of the surface inch, although it may be noted also in the acetic acid soluble $\mathrm{P}$ in the layer from 1 to 3 inches. But in no case has it reached the layer from 3 to 5 inches.

In order to get more information of the forms in which the applied phosphates occur in the soils, a fractionation was carried out. According to CHANG and JACKSON (1) successive extractions with $0.5 \mathrm{~N}$ neutral $\mathrm{NH}_{4} \mathrm{~F}, 0.1 \mathrm{~N} \mathrm{NaOH}$, and $0.5 \mathrm{~N} \mathrm{H}_{2} \mathrm{SO}_{4}$ dissolve the Al-bound $\mathrm{P}$, the Fe-bound $\mathrm{P}$, and the Ca-bound $\mathrm{P}$, respectively. Since there was no reason to suppose that within the short period of the experiments any fertilizer phosphorus had been fixed as occluded $\mathrm{Fe}-\mathrm{Al}$ phosphates, the fractionation was not carried out to estimate these forms. No distinct differences could be detected in the organic phosphorus content of the variously treated soils. The results of the fractionation of the inorganic phosphorus in the samples from four of the treatments are reported in Table 4 for trial $\mathrm{K} 100$ and in Table 5 for trial K 101.

In spite of the different acidity of the two experimental soils, the main features shown by the data for the $\mathrm{P}$ fractions are fairly equal. In both soils the Ca-bound $\mathrm{P}$ is by far the largest fraction, and the Al-bound $\mathrm{P}$ is least in evidence. In the less acid soil of trial $\mathrm{K} 101$ the $\mathrm{Ca}$-bound $\mathrm{P}$ is somewhat higher and the sesquioxidebound $\mathrm{P}$ somewhat lower than in the soil of trial $\mathrm{K} 100$. In both soils the differences caused by the phosphate fertilizers in the various fractions are strikingly similar.

Table 4. Fractions of inorganic $\mathrm{P}$ in the soil of trial $\mathrm{K} 100$ in 1958

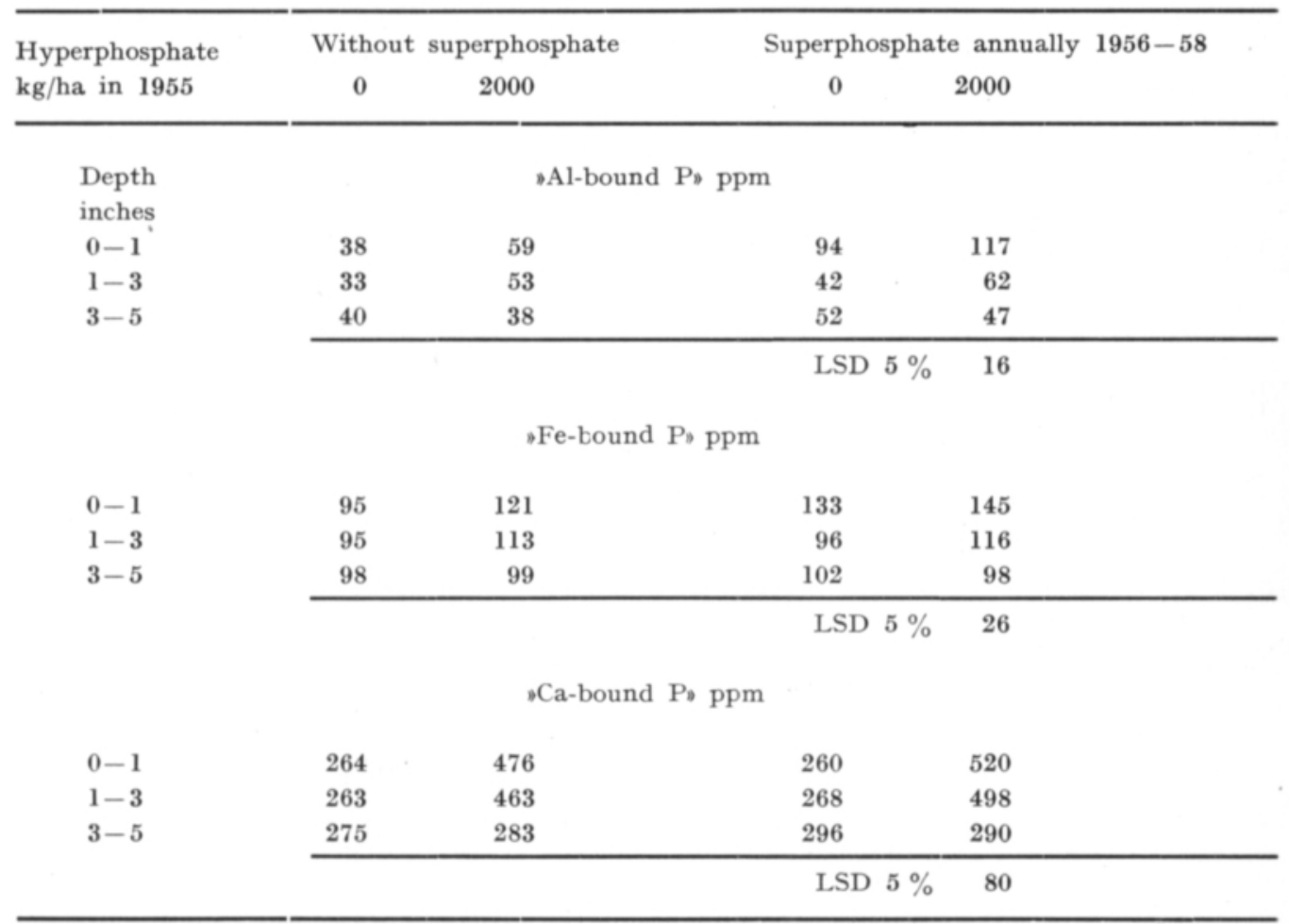


Table 5. Fractions of inorganic $\mathrm{P}$ in the soil of trial $\mathrm{K} 101$ in 1959

\begin{tabular}{lcccc}
\hline Hyperphosphate & Without superphosphate & \multicolumn{2}{c}{ Superphosphate annually } & $1956-59$ \\
$\mathrm{~kg} / \mathrm{ha}$ in 1955 & 0 & 2000 & 0 & 2000
\end{tabular}

Depth

\begin{tabular}{lllll}
$0-1$ & 24 & 40 & 68 & 92 \\
$1-3$ & 19 & 26 & 26 & 42 \\
$3-5$ & 19 & 24 & 23 & 20 \\
\hline
\end{tabular}

•Fe-bound, $\mathrm{P}$ ppm

\begin{tabular}{rrrrr}
$0-1$ & 64 & 94 & 106 & 134 \\
$1-3$ & 60 & 78 & 70 & 89 \\
$3-5$ & 59 & 69 & 64 & 72 \\
\hline
\end{tabular}

Ca-bound, P ppm

\begin{tabular}{lllll}
$0-1$ & 346 & 541 & 350 & 600 \\
$1-3$ & 351 & 464 & 349 & 568 \\
$3-5$ & 356 & 349 & 366 \\
\hline
\end{tabular}
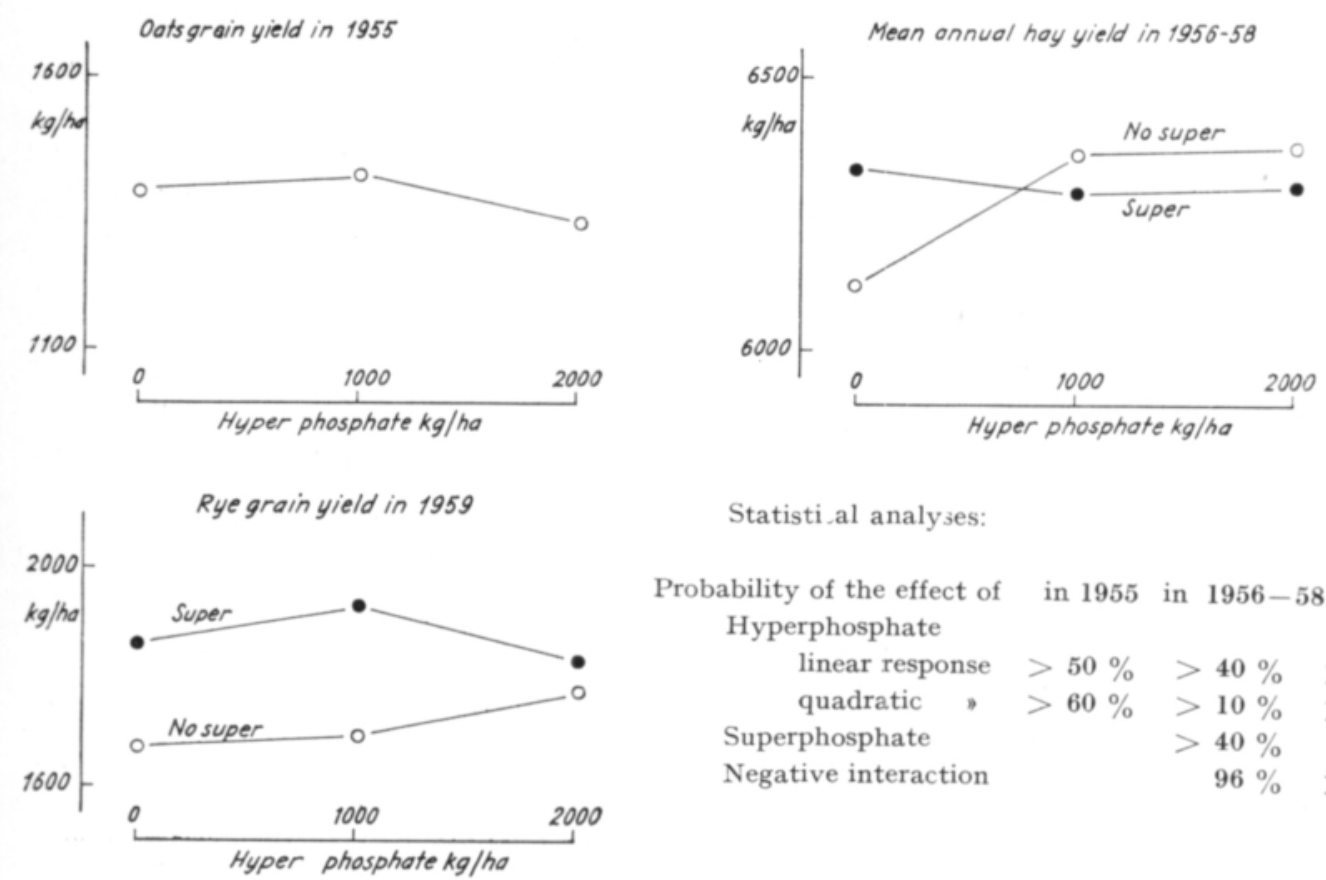

Statisti al analy ses:

Probability of the effect of in 1955 in $1956-58$ in 1959

Hyperphosphate

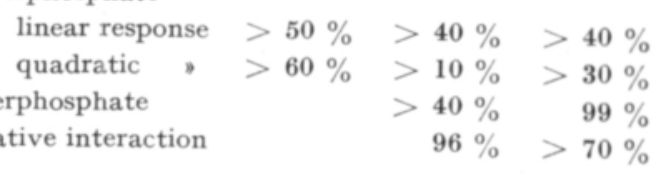

Fig. 1. Yield results in trial K 100 
The effect of superphosphate may be seen only in the Al-bound and Fe-bound $\mathrm{P}$ of the surface inch. The rock phosphate phosphorus has mostly increased the Cabound fraction of the two highest layers, but also, to a rather low extent, the $\mathrm{Al}$ bound $\mathrm{P}$. These results also unmistakably prove that the rock phosphate has not penetrated deeper than to the second layer, although it was worked into the soil by spade harrow.

\section{Yield results}

The yield results from trial $\mathrm{K} 100$ are presented by the graphs in Figure 1 . In this trial the effect of phosphate fertilizers was rather poor. The nurse crop, "Ehon-oats, did not response to hyperphosphate, and neither was this store dressing able to produce sijgnificant increases in the average hay yields nor in the yield of rye. But there is a statistically significant negative interaction to be found between the effects of the hyperphosphate store dressing and the annual surface application of superphosphate. In each year the hay yields from the plots without hyperphosphate were higher from the subplots treated with superphosphate than from the untreated halves, but no response to superphosphate could be found in connection with the store dressing. On the other hand, the residual effect of superphosphate on the rye crop was marked. This crop is known to benefit from phosphate fertilizers under the conditions of our country, not least in overwintering and in resistance to low-
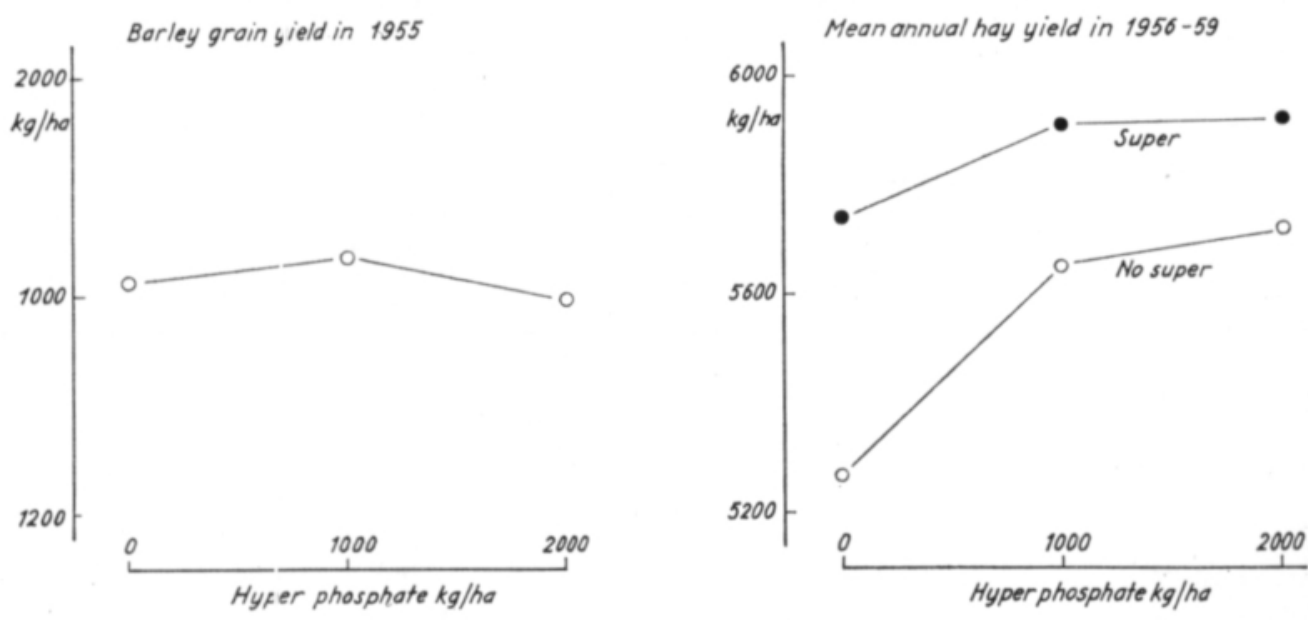

Statistical analyses:

Probe.bility of the effect of

Hyperhosphate

linear response quadratic response

Superphosphate

Negative interaction

$\begin{array}{rr}\text { in } 1955 & \text { in } 1956-59 \\ >10 \% & 91 \% \\ >50 \% & >50 \% \\ & 99.9 \% \\ 95 \%\end{array}$

Fig. 2. Yield results in trial K 101 
temperature parasitic fungi. It may be mentioned that the winter $1958-59$ was a fairly bad snow mould season, and the variety used, "Toivo"-rye, is susceptible to Fusarium nivale. On the other hand, the fact must be remembered that the superphosphate applied as a surface dressing to the ley and retained by the surface inch of the soil, was now ploughed into deeper layers and thus came within the reach of the rye roots.

The graphs in Figure 2 show the yield results from trial K 101. Nor did the nurse crop, "Baldern-barley, respond to hyperphosphate in this trial. As a matter of fact, this was a good thing: it is possible that an intensive effect of fertilizers on the cover-crop may bring about such a rank growth that it will cause a secondary decrease in yield in the first ley year.

In this trial the store dressing with hyperphosphate has produced a slight response in the hay yields. It also has improved the phosphorus condition of the soil, since a statistically significant negative interaction may be found between the effects of hyperphosphate and superphosphate. In spite of that, the effect of superphosphate in this trial has been very good, even in connection with the hyperphosphate dressing.

It may be mentioned that in these trials no significant differences in the clover content of the hay could be detected between the various treatments.

\section{Phosphorus uptake by the ley crop of trial K 101 in 1959}

In order to get more information about the phosphorus nutrition of the ley plants in the variously treated plots, hay samples were collected from trial K 101 in 1959 and analyzed for phosphorus. These results are recorded in Table 6.

Table 6. Phosphorus in the hay yield from trial $\mathrm{K} 101$ in 1959

\begin{tabular}{lrrrrrrr}
\hline \multirow{2}{*}{$\begin{array}{l}\text { Hyperphosphate } \\
\mathrm{kg} / \mathrm{ha} \text { in } 1955\end{array}$} & \multicolumn{3}{c}{ Without superphosphate } & \multicolumn{2}{c}{ Superphosphate annually } & LSD $5 \%$ \\
& 0 & 1000 & 2000 & 0 & 1000 & 2000 \\
\hline
\end{tabular}

It may be noted that although the response of the dry matter yield to hyperphosphate was not quite significant, hyperphosphate did improve the phosphorus conditions in soil to such a degree that the $\mathrm{P}$ content of the hay quite markedly increased. In the amount of phosphorus in the hay yield the effect of hyperphosphate is also significant.

The annual superphosphate application guaranteed the production of hay of a satisfactory quality. The combined effect of the hyperphosphate store dressing and the annual superphosphate treatment resulted in the production of hay with a quite high $\mathrm{P}$ content. 


\section{Discussion}

The object of the present study was to try to find out whether it is possible to improve the phosphorus status by a store dressing with hyperphosphate to such a degree that an annual application of superphosphate would no longer be profitable. The material is, of course, far too small to give a reliable answer to this rather complicated question, but some interesting hints could be obtained, particularly for further studies.

First, it seems that a store dressing with $1000 \mathrm{~kg} / \mathrm{ha}$ of hyperphosphate is probably too low to produce the effect wanted, and that even higher amounts than $2000 \mathrm{~kg} / \mathrm{ha}$ of hyperphosphate may be recommendable under our conditions for a really distinct result. Second, it appears that the working of hyperphosphate into soil by a spade harrow did not, in spite of the very careful performance, bring the fertilizer deeper than to the layer from 1 to 3 inches, with a large part remaining in the surface inch. This means that the most effective uptake of phosphorus from the fertilizer was not guaranteed.

The retention of superphosphate phosphorus by the surface inch in both the trials could be excepted. Thus, even its effect could not be the best possible. That it, in every case, was able to improve the phosphorus nutrition of the ley plants may be attributed to the effective uptake of phosphorus by the roots near the surface, or perhaps $\epsilon$ ven to some absorption of phosphorus by the living foliage in the spring.

The working in of the broadcasted fertilizers is a difficult problem which under dry periods may be of importance even in connection with fertilizers as soluble as nitrates, a fact which could be detected by the authors in some other experiments. Recently, RID and Süss (3) have shown that the common techniques seldom do bring about an ideal distribution of phosphate fertilizers in the soil. Yet, the methods employed in the present trials were equal to the common cultivation technique in our country, and thus, they correspond to the conditions in practice.

In spite of the fact that according to the chemical analyses, the soil in trial $\mathrm{K} 100$ was "poore:" than that in trial $\mathrm{K} 101$, the response to phosphate fertilizers in the former was very slight, and, the level of yields, particularly that of the hay yields, was fairly high. In trial K 101, the effect of phosphates was more distinct.

In both trials, however, a statistically significant negative interaction between the effects of the fertilizers was found. This may be taken to indicate that it is possible to improve the phosphorus status of a soil with a store dressing with hyperphosphate to some degree. Experiments placed on soils with a markedly lower phosphorus status; and carried out with heavier store dressings may give a more positive answer to this question. 
The possibility of improving the soil phosphorus status by a store dressing with rock phosphate has been studied in two field trials of five years standing. Hyperphosphate Reno was applied to the nurse crop of a red clover-timothy ley in amounts of $0,1000 \mathrm{~kg} / \mathrm{ha}$, or $2000 \mathrm{~kg} / \mathrm{ha}$, respectively. The split-plot technique was used to study the response of the ley to an additional annual application of $200 \mathrm{~kg} / \mathrm{ha}$ of superphosphate.

The soil analyses distinctly proved that, in spite of a careful working in of the hyperphosphate with a spade harrow, the fertilizer had not penetrated deeper than to the layer from 1 to 3 inches, with a large part of it remaining in the top inch. The treatment with hyperphosphate had mostly increased the fraction of the calcium-bound phosphorus, and, to a very low degree, the aluminium-bound phosphorus. The effect of superphosphate could be detected only in the fractions of aluminium- and iron-bound phosphorus of the surface inch.

Although the store dressing did not produce marked responses in the yields of either trial, the statistically significant negative interaction between the effect of it and of superphosphate may be taken to indicate that hyperphosphate was able to improve the phosphorus status of these soils to some degree. The analyses of the hay samples from one of the trials in the fifth experimental year showed that the store dressing, particularly with the higher amount of hyperphosphate was able to increase the phosphorus content of hay to a satisfactory level which was equal to that produced by the annual superphosphate dressing only. Their combined effect resulted in the production of hay dry matter containing more than $0.24 \%$ of $\mathrm{P}$.

In one of the experiments the residual effect of the treatments on rye was studied. The response to superphosphate was highly significant, probably owing to the high demands of phosphorus by rye, connected with the overwintering conditions, and also to the fact that ploughing in of the ley had brought superphosphate phosphorus within the reach of the plant roots.

\section{REFERENCES}

(1) Chang, S. C. \& Jackson, M. L. 1957. Fractionation of soil phosphorus. Soil Sci. 84: $133-144$.

(2) Gericke, S. \& Kurmies, B. 1952. Die kolorimetrische Phosphorsäurebestimmung mit AmmoniumVanadat-Molybdat und ihre Anwendung in der Pflanzenanalyse. Z. Pflanzenern., Dgg., Bodenk. 59: 235-247.

(3) Rid, H. \& Sưss, A. 1959. Der Mischeffekt verschiedener Bodenbearbeitungsgeräte und sein Einfluss auf die Phosphateaufnahme von Sommergerste und Sommerraps nachgewiesen durch P32. Z. Acker u. Pflanzenbau 109: 229-254.

(4) TERÄSvUORI, A. 1954. Uber die Anwendung saurer Extraktionslösungen zur Bestimmung des Phosphordüngerbedarfs des Bodens, nebst theoretischen Erörterungen über den Phosphorzustand des Bodens. Publ. Staatl. Landw. Versuchsw. Finland N:r 141. Helsinki, 64 p. 
SELOST US:

JERUSLANNOITUSKOKEITA HIENOFOSFAATILLA

\author{
Pentti Hänninen
}

Maatalouden tutkimuskeskus, Keski-Suomen liikkuva koetoiminta

ARmi KaILA

Helsingin yliopiston maanviljelyskemian laitos

Tutkimuksessa on selostettu kahden viisivuotisen kenttäkokeen tuloksia. Hienofosfaattiperuslannoituksen tehokkuutta on verrattu lisäksi annetun vuotuisen superfosfaattilannoituksen vaikutukseen.

Maa-analyysit osoittivat (taulukot $2-5$ ), että huolimatta huolellisesta multauksesta traktoriSampolla hienofosfaatista suuri osa oli jäänyt aivan pintaan $(0-2.5 \mathrm{~cm})$ tai joutunut enintään seuraavaan kerrokseen $(2.5-7.5 \mathrm{~cm})$. Hienofosfaatti oli lisännyt lähinnä kalsiumin sitomaa epäorgaanista fosforia ja vain hiukan aluminiumin sitomaa fosforia. Sen sijaan superfosfaatti, joka oli pidättynyt kokonaan pintakerrolsen $(0-2.5 \mathrm{~cm})$ oli lisännyt seskvioksidien sitomaa fosforia.

Joskaan hienofcsfaattiperuslannoituksella ei saatu merkittäviä sadon lisäyksiä kummassakaan kokeessa (piirrokset 1 ja 2), tilastollisesti selvä negatiivinen yhteisvaikutus (interaktio) superfosfaatin kanssa osoitti kuiten kin, että hienofosfaatti oli jossain määrin parantanut maan fosforitilannetta. Heinäanalyysit osoittivat (taulukko 6), että hienofosfaatti oli pystynyt nostamaan neljännen vuoden heinän fosforin pitoisuuden tyydyttävälle tasolle, samalle kuin pelkkä vuotuinen superfosfaattilannoitus. Molempien yhteisvaikutus tuotti yli $0.24 \%$ fosforia sisältãvää heinäă.

Toisessa kokeessa tutkittiin myös lannoituksen jälkivaikutusta rukiilla. Hienofosfaatin ei todettu vaikuttaneen rukiin jyväsatoon, mutta sen sijaan superfosfaatin vaikutus oli erittäin selvä (piirros 1). Tämä johtunee osittain rukiin suuresta fosforin tarpeesta, joka osaltaan kytkeytyy talvehtimisolosuhteisiin, osittain tieter kin siitä, että pintaan pidättynyt superfosfaatti joutui kynnettäessä paremmin kasvin juurten ulottuville. 